\title{
PENGARUH KONSENTRASI PUPUK HAYATI BIOBOOST DAN AIR KELAPA TERHADAP PERTUMBUHAN DAN HASIL TANAMAN SELADA (Lactuca sativa L.) VARIETAS GRAND RAPIDS
}

\author{
Oleh: \\ Kovertina Rakhmi Indriana \\ Ricky Hasrat Dirmawan \\ Ai Komariah \\ E-mail: \\ kovertina.rakhmi.indriana@gmail.com dan rickyhasrat.12d@gmail.com \\ Program Studi Agroteknologi Fakultas Pertanian Universitas Winaya Mukti
}

\begin{abstract}
ABSTRAK
Percobaan ini dilakukan di Desa Cikondang, Kecamatan Ganeas, Kabubaten Sumedang, dengan ketinggian tempat 500 meter di atas permukaan laut, ordo tanah Podsolik dan PH 4.5 - 6.5. Tujuan percobaan ini untuk mengetahui dan mempelajari pengaruh pemberian konsentrasi pupuk hayati bioboost dan air kelapa terhadap pertumbuhan dan hasil tanaman selada varietas grand rapids. Rancangan yang digunakan adalah Rancangan Acak Kelompok (RAK) pola faktorial yang terdiri dua faktor dan diulang dua kali. Faktor pertama adalah pupuk hayati bioboost (u) yang terdiri dari empat taraf, yaitu : $\mathrm{u}_{0}=0 \mathrm{ml} / \mathrm{L}$ larutan, $\mathrm{u}_{1}$ $=25 \mathrm{ml} / \mathrm{L}$ larutan, $\mathrm{u}_{2}=50 \mathrm{ml} / \mathrm{L}$ larutan, $\mathrm{u}_{3}=75 \mathrm{ml} / \mathrm{L}$ larutan. Faktor kedua adalah air kelapa (a) yang terdiri dari empat taraf, yaitu : $\mathrm{a}_{0}=0 \mathrm{ml} / \mathrm{L}$ larutan, $\mathrm{a}_{1}=75 \mathrm{ml} / \mathrm{L}$ larutan, $\mathrm{a}_{2}=$ $150 \mathrm{ml} / \mathrm{L}$ larutan, $a_{3}=225 \mathrm{ml} / \mathrm{L}$ larutan. Hasil percobaan menunjukan bahwa terjadi interaksi terhadap (tinggi tanaman umur 35 HST, volume akar, bobot segar per plot dan nisbah pupus akar) dan tidak terjadi interaksi (tinggi tanaman umur 14 HST, 21 HST, 28 HST, jumlah daun umur 14 HST, 21 HST, 28 HST, 35 HST, bobot segar per tanaman dan bobot kering ).
\end{abstract}

Kata Kunci : Pupuk hayati bioboost; Air kelapa, Selada.

\section{ABSTRAC}

This experiment was carried out in Cikondang Village, Ganeas subdistrict, Sumedang Regency, with an altitude of 500 meters above sea level, Podsolik soil order and PH 4.5 - 6.5. The purpose of this experiment was to determine and study the effect of concentration bioboost bio fertilizer and coconut water on the growth and yield of lettuce varieties of grand rapids. The design used was a Randomized Block Design (RBD) with factorial pattern was consisted of two factors and replicated twice. The first factors is bioboost bio fertilizer (u) which consists of four levels, it's : $u_{0}=0 \mathrm{ml} / \mathrm{L}$ solution, $u_{1}=25 \mathrm{ml} / \mathrm{L}$ solution, $u_{2}=50$ $\mathrm{ml} / \mathrm{L}$ solution, $u_{3}=75 \mathrm{ml} / \mathrm{L}$ solution. The second factor is coconut water (a) which consists of four levels, it's : $a_{0}=0 \mathrm{ml} / L$ solution, $a_{1}=75 \mathrm{ml} / L$ solution, $a_{2}=150 \mathrm{ml} / \mathrm{L}$ solution, $a_{3}=225 \mathrm{ml} /$ $L$ solution. The experimental results was indicated the interaction on the (plant height aged 35 HST, root volume, fresh weight per plot and root shoot ratio) and no interaction (plant height aged 14 HST, 21 HST, 28 HST, number of leaves aged 14 HST, 21 HST, 28 HST, 35 HST, fresh weight per plant and dry weight.

Keywords: Bioboost bio fertilizer; Coconut Water; Lettuce.

PENGARUH $\quad$ KONSENTRASI $\quad$ PUPUK HAYATI BIOBOOST DAN AIR KELAPA TERHADAP PERTUMBUHAN DAN HASIL TANAMAN SELADA ( Lactuca sativa L.)

VARIETAS GRAND RAPIDS
KOVERTINA RAKHMI INDRIANA RICKY HASRAT DIRMAWAN dan AI KOMARIAH 


\section{PENDAHULUAN}

Selada (Lactuca sativa L.) merupakan salah satu tanaman komoditi sayuran hortikultura yang memiliki prospek dan nilai ekonomi yang cukup baik. Tanaman selada memiliki kandungan gizi yang diperlukan oleh tubuh seperti protein, karbohidrat, Vitamin A, B dan C. Sunarjono (2007) kandungan vitamin A, B, C, karbohidrat dan serat pada selada berguna untuk kesehatan tubuh. Sama halnya seperti sayuran wortel tanaman selada memiliki kandungan vitamin A yang cukup tinggi yaitu sebesar 7405 IU yang dibutuhkan oleh tubuh guna memacu sistem kekebalan tubuh serta berperan pada kesehatan kornea mata (Bargumono, 2016).

Kandungan gizi selada tergolong lengkap. Kandungan gizi per 100 gram dalam daun selada segar yaitu air 94,98 gr, kalori atau energi 15,0 kal, protein 1,36 gr, karbohidrat 2,97 gr, serat 1,3 gr, vitamin A $7405 \mathrm{IU}$, kemudian vitamin C 9,2 mg dan vitamin B1 sebesar 0,090 mg. USDA (2014).

Kebutuhan tanaman selada di Indonesia saat ini belum dapat terpenuhi karena rata-rata masyarakat Indonesia hanya mengonsumsi sayuran sekitar 91 gram/hari. Angka tersebut masih jauh dari standar kecukupan gizi sehat yaitu sekitar 455 gram/hari atau 91,25 kilogram/kapita/tahun. Laju pertumbuhan produksi selada pada tahun 2010-2015 yaitu 5,19-6\% per tahun. Sedangkan produksi selada dalam skala nasional masih lebih rendah dari konsumsi yakni sebesar 35,30 $\mathrm{kg} / \mathrm{kapita} /$ tahun. Sementara itu, selada pada volume impor di tahun 2015 yaitu 21,1 ton sehingga dapat menjadi peluang untuk meningkatkan produksi tersebut agar mampu memenuhi tingkat konsumsi selada secara nasional (BPS, 2016).

Sejalan dengan adanya kemajuan teknologi, kini telah ditemukan jenis pupuk baru yaitu pupuk hayati yang memiliki mikroba sebagai penyubur tanah. Dengan adanya kandungan mikroba sehingga mampu membuat pupuk ini menjadi ramah lingkungan. Selain dair itu, mikroba tersebut bermanfaat untuk proses biokimia di dalam tanah dan unsur hara tersebut akan menjadi lebih mudah diserap oleh akar tanaman sehingga tanaman akan tumbuh lebih optimal. Selain itu, pupuk hayati ini mengadung bakteri-bakteri yang bermanfaat untuk memacu terhadap pertumbuhan tanaman agar hasil produksi tanaman tersebut tetap tinggi dan berkelanjutan. Menurut Hartatik (2006) bahwa selain bermanfaat untuk sumber energi bagi aktivitas mikroba dalam tanah dan sumber hara, tetapi pupuk organik ini memiliki kelebihan dalam memperbaiki kesuburan kimia, fisika dan biologi tanah.

Salah satu produk pupuk hayati yang beredar dipasaran saat ini adalah Bioboost. Mitra Petani (2011) menyatakan bahwa bioboost adalah salah satu pupuk hayati yang memiliki kandungan mikroorganisme tanah yang unggul dan bermanfaat dalam meningkatkan kesuburan tanah serta meningkatkan mutu maupun jumlah hasil panen. Bioboost mengandung berbagai macam mikroorganisme sebagai berikut (1) Azotobacter sp 2,5 x $108-105 \mathrm{cf \mu} / \mathrm{ml}$, berperan sebagai penambat nitrogen, (2) Azospirillum sp 3 × $107-105 \mathrm{cf} \mu / \mathrm{ml}$, berperan sebagai penambat nitrogen, (3)

PENGARUH $\quad$ KONSENTRASI $\quad$ PUPUK HAYATI BIOBOOST DAN AIR KELAPA TERHADAP PERTUMBUHAN DAN HASIL TANAMAN SELADA ( Lactuca sativa L.)

VARIETAS GRAND RAPIDS
KOVERTINA RAKHMI INDRIANA RICKY HASRAT DIRMAWAN dan AI KOMARIAH 
Bacillus sp 3,5 x 107 - $105 \mathrm{cf} \mu / \mathrm{ml}$, berperan dalam dekomposisi bahan organik, (4) Pseudomonas sp $7 \times 105-104 \mathrm{cf} \mu / \mathrm{ml}$, berperan dalam dekomposisi residu pestisida, dan (5) Cytophaga sp 1,5 x $104-103 \mathrm{cf} \mu / \mathrm{ml}$, berperan dalam proses dekomposisi bahan organik. Pupuk Bioboost diketahui juga mengandung hormon pertumbuhan alami seperti giberellin, sitokinin, kinetin, zeatin, serta auksin (IAA) (Bioboostsakti, 2016 ).

Manfaat pupuk hayati Bioboost yaitu untuk tanaman sayuran agar tanaman tumbuh lebih baik. Penyebab utamanya adalah adanya mikroorganisme secara efektif dapat meningkatkan penyerapan unsur hara makro atau mikro selain itu akar tanaman yang bermikroriza dapat menyerap unsur hara secara bentuk terikat dan tidak tersedia bagi tanaman (Ananta, 2012).

Pertumbuhan tanaman selada tidak terlepas dari unsur yang akan diserap oleh tanaman untuk menunjang perkembangan dan pertumbuhannya. Unsur tersebut dapat diperoleh dari pupuk yang diberikan oleh media tanam. Jika unsur-unsur terkandung dalam pupuk yang dibutuhkan tanaman selda dapat terpenuhi dengan tepat dan cukup, tanaman selada akan menghasilkan pertumbuhan dan produksi yang optimal. Selain unsur hara, tanaman selada juga sangat membutuhkan zat pengatur tumbuh (ZPT). Zat pengatur tumbuh (ZPT) dapat memberikan rangsangan bagi tanaman selada. Salah satu ZPT yang dapat digunakan dan menghasilkan nutrisi alami adalah air kelapa.

Air kelapa mempunyai banyak kandungan homon yang dapat digunakan sebagai ZPT pada tanaman sayuran. Air kelapa merupakan suatu sumber alami hormon tumbuh bermanfaat untuk memacu pembelahan sel dan merangsang pertumbuhan tanaman. Hormon yang terkandung di dalam air kelapa tersebut diantara lain auksin, sitokinin dan giberelin. Air kelapa selain mengandung mineral juga mengandung sitokini yang berfungsi untuk mempergiat pembelahan sel serta pertumbuhan tunas dan akar. Hormon auksin dan sitokinin dapat menjadi pendukung dalam pembelahan sel embrio. Berdasarkan hal itu, perlu adanya pengujian terhadap respon air kelapa sebagai zat pengatur tumbuh (ZPT) dengan konsentrasi yang diberikan.

\section{METODOLOGI}

Percobaan ini dilaksanakan di Desa Cikondang, Kecamatan Ganeas, Kabubaten Sumedang, pada bulan juni 2020 sampai dengan bulan juli 2020, dengan ketinggian tempat 500 meter di atas permukaan laut, ordo tanah podsolik dan $\mathrm{pH} 4.5$ - 6.5 (asam). Tipe curah hujan di wilayah Ganeas termasuk tipe curah hujan C (agak basah) (UPTD Ganeas, 2019).

Bahan-bahan yang digunakan dalam percobaan ini adalah tanah dari kebun Pribadi Dusun Cigobang, Desa Cikondang, Kecamatan Ganeas, benih selada varietas Grand Rapids, pupuk hayati Bioboost, air kelapa, pupuk kandang ayam, air, 
Decis 2,5 EC dan Fungisida Dithane M-45 80 WP, cangkul, kored, cuter, polybag ukuran 40x40 cm, kored, paranet, gembor, bambu, kokeran, label, ember, mistar ukur, timbangan, penggaris, ayakan ukuran $2 \mathrm{~mm}$, beaker glass, suntikan, kamera dan alat-alat tulis.

Penelitian ini menggunakan Rancangan Acak Kelompok dua faktor yang yaitu faktor pertama konsentrasi pupuk Bioboost (u) yang terdiri dari 4 taraf perlakuan, dimana $\mathrm{u} 0=0 \mathrm{ml} \mathrm{L}-1, \mathrm{u} 1=40 \mathrm{ml} \mathrm{L}-1, \mathrm{u} 2=80 \mathrm{ml} \mathrm{L}-1$, dan $\mathrm{u} 3=120 \mathrm{ml} \mathrm{L}-1$. Kemudian faktor kedua konsentrasi Air Kelapa (a) yang terdiri dari empat taraf perlakuan, dimana a0 $=0 \mathrm{ml} \mathrm{L}-1, \mathrm{a} 1=75 \mathrm{ml} \mathrm{L}-1$, a2 $=150 \mathrm{ml} \mathrm{L}-1$, dan a3 $=225 \mathrm{ml}$ L-1. Dari kedua faktor diperoleh 16 kombinasi perlakuan, sehingga jumlah plot percobaan dengan dua kali ulangan sebanyak 32 plot, populasi tanaman per plot adalah 6 sehingga jumlah populasi seluruhnya 192 tanaman.

statistik dengan analisis ragam pada taraf 5\%, jika berpengaruh nyata maka dilanjutkan dengan uji wilayah berganda Duncan Multiple Range Test (DMRT) pada $\operatorname{taraf} 5 \%$.

Parameter yang diamati dalam penelitian ini meliputi : Tinggi tanaman, jumlah daun,berat segar tanaman, berat segar per plot, nisbah pupus akar, berat kering tanaman, dan volume akar. Volume akar $(\mathrm{ml})$, di hitung setelah proses pemanenan dilakukan dengan menggunakan gelas ukur dan dilakukan pada akhir percobaan, dimana gelas ukur diisi dengan air kemudian volume air di ukur (V1), selanjutnya akar di masukan kedalam gelas ukur tersebut kemudian volume air kembali diukur (V2). Volume akar dihitung dengan rumus : V2 - V1.

\section{HASIL DAN PEMBAHASAN}

\section{A. Hasil Percobaan}

\section{a. Pengamatan Penunjang}

Berdasarkan hasil penelitian ada beberapa hal yang harus diperhatikan pada saat sebelum dan sesudah penelitian yaitu analisis tanah sebelom percobaan, suhu dan kelembaban harian selama percobaan, pengendalian serangan hama dan penyakit, kemudian pengendalian gulma di lokasi percobaan.

\section{b. Pengamatan Utama}

\section{Tinggi Tanaman $(\mathrm{cm})$}

Data pengamatan dan analisis tinggi tanaman pada umur 14 HST, 21 HST, 28 HST dan 35 HST, hasil analisis ragam menunjukan terjadi interaksi antara perlakuan pupuk hayati bioboost dan air kelapa terhadap tinggi tanaman umur 35 HST, namun pada umur pengamatan lainnya tidak terjadi interaksi. Hasil analisis uji jarak berganda Duncan secara mandiri dapat dilihat pada (Tabel 1) dan hasil uji lanjutan secara efek sederhana seperti tersaji pada (Tabel 2).

PENGARUH KONSENTRASI PUPUK HAYATI BIOBOOST DAN AIR KELAPA TERHADAP PERTUMBUHAN DAN HASIL TANAMAN SELADA ( Lactuca sativa L.)

VARIETAS GRAND RAPIDS
KOVERTINA RAKHMI INDRIANA RICKY HASRAT DIRMAWAN dan AI KOMARIAH 
Tabel 1. Pengaruh Pemberian Konsentrasi Bioboost dan Air Kelapa terhadap Tinggi Tanaman Umur 14 HST, 21 HST dan 28 HST.

\begin{tabular}{lccc}
\hline \multicolumn{1}{c}{ Perlakuan } & \multicolumn{3}{c}{ Rata-Rata Tinggi Tanaman (cm) } \\
\cline { 2 - 4 } Pupuk hayati Bioboost & $\mathbf{1 4}$ hst & $\mathbf{2 1 ~ h s t}$ & $\mathbf{2 8 ~ h s t}$ \\
$\mathrm{u}_{0}=0 \mathrm{ml} /$ L Larutan & $13,94 \mathrm{a}$ & $18,56 \mathrm{a}$ & $22,35 \mathrm{a}$ \\
$\mathrm{u}_{1}=40 \mathrm{ml} /$ L Larutan & $14,88 \mathrm{ab}$ & $20,66 \mathrm{~b}$ & $23,21 \mathrm{a}$ \\
$\mathrm{u}_{2}=80 \mathrm{ml} /$ L Larutan & $15,06 \mathrm{~b}$ & $21,17 \mathrm{~b}$ & $24,88 \mathrm{~b}$ \\
$\mathrm{u}_{3}=120 \mathrm{ml} /$ L Larutan & $15,77 \mathrm{~b}$ & $22,37 \mathrm{c}$ & $25,16 \mathrm{~b}$ \\
\hline Air Kelapa & & & \\
$\mathrm{a}_{0}=0 \mathrm{ml} / \mathrm{L}$ Larutan & $13,63 \mathrm{a}$ & $18,21 \mathrm{a}$ & $21,46 \mathrm{a}$ \\
$\mathrm{a}_{1}=75 \mathrm{ml} / \mathrm{L}$ Larutan & $15,51 \mathrm{~b}$ & $20,90 \mathrm{~b}$ & $24,41 \mathrm{~b}$ \\
$\mathrm{a}_{2}=150 \mathrm{ml} /$ L Larutan & $14,49 \mathrm{a}$ & $21,35 \mathrm{bc}$ & $24,63 \mathrm{~b}$ \\
$\mathrm{a}_{3}=225 \mathrm{ml} / \mathrm{L}$ Larutan & $16,02 \mathrm{~b}$ & $22,30 \mathrm{c}$ & $25,11 \mathrm{~b}$ \\
\hline
\end{tabular}

Keterangan : Angka rata-rata yang diikuti huruf yang sama berbeda tidak nyata berdasarkan Uji Jarak Berganda Duncan pada taraf nyata $5 \%$.

Berdasarkan Tabel 1, hasil analisis uji mandiri menunjukkan bahwa pemberian konsentrasi pupuk hayati bioboost menunjukkan hasil yang berbeda nyata terhadap pertumbuhan tinggi tanaman umur 14 HST, 21 HST, dan 28 HST. Perlakuan $\mathrm{u}_{3}$ konsentrasi $\left(120 \mathrm{ml} \mathrm{L}^{-1}\right)$ menunjukkan hasil yang tinggi dibandingkan perlakuan lainya. Demikian pula pemberian konsentrasi air kelapa menunjukkan hasil yang berbeda nyata terhadap pertumbuhan tinggi tanaman umur 14 HST, 21 HST, dan 28 HST, perlakuan $\mathrm{a}_{3}$ konsentrasi $\left(225 \mathrm{ml} \mathrm{L}^{-1}\right)$ menunjukkan hasil yang tinggi dibandingkan perlakuan lainya.

Tabel 2. Pengaruh Pemberian Konsentrasi Bioboost dan Air Kelapa terhadap Tinggi Tanaman Umur 35 HST.

\begin{tabular}{|c|c|c|c|c|}
\hline \multirow{3}{*}{$\begin{array}{l}\text { Pupuk hayati } \\
\text { Bioboost ( u ) }\end{array}$} & \multicolumn{4}{|c|}{ Rerata Tinggi Tanaman $(\mathrm{cm})$} \\
\hline & \multicolumn{4}{|c|}{ Air kelapa ( a ) } \\
\hline & $a_{0}(0 \mathrm{ml} / \mathrm{L})$ & $a_{1}(75 \mathrm{ml} / \mathrm{L})$ & $a_{2}(150 \mathrm{ml} / \mathrm{L})$ & $\begin{array}{l}\mathrm{a}_{3}(225 \\
\mathrm{ml} / \mathrm{L})\end{array}$ \\
\hline \multirow[t]{2}{*}{$\mathrm{u}_{0}(0 \mathrm{ml} / \mathrm{L})$} & $26,28 \mathrm{a}$ & $26,50 \mathrm{a}$ & $26,72 \mathrm{a}$ & $26,22 \mathrm{a}$ \\
\hline & A & A & A & A \\
\hline \multirow[t]{2}{*}{$\mathrm{u}_{1}(40 \mathrm{ml} / \mathrm{L})$} & $27,37 \mathrm{a}$ & $31,50 \mathrm{~b}$ & $32,58 \mathrm{~b}$ & $34,62 \mathrm{~b}$ \\
\hline & A & B & B & C \\
\hline \multirow{2}{*}{$\mathrm{u}_{2}(80 \mathrm{ml} / \mathrm{L})$} & $27,85 \mathrm{ab}$ & $33,25 \mathrm{~b}$ & $32,65 \mathrm{~b}$ & $32,68 \mathrm{c}$ \\
\hline & A & $\mathrm{B}$ & $\mathrm{B}$ & $\mathrm{B}$ \\
\hline \multirow[t]{2}{*}{$\mathrm{u}_{3}(120 \mathrm{ml} / \mathrm{L})$} & $29,67 \mathrm{~b}$ & $33,47 \mathrm{~b}$ & $34,72 \mathrm{c}$ & $35,85 \mathrm{c}$ \\
\hline & A & $\mathrm{B}$ & $\mathrm{C}$ & $\mathrm{C}$ \\
\hline
\end{tabular}

Keterangan : Angka rata-rata yang ditandai dengan huruf kecil (arah vertikal ) dan huruf kapital (horizontal) yang sama menunjukan berbeda tidak nyata berdasarkan Uji Jarak Berganda Duncan pada taraf nyata $5 \%$.

Berdasarkan Tabel 2, menunjukan bahwa pada taraf $a_{3}$, pemberian konsentrasi pupuk hayati bioboost pada taraf $\mathrm{u}_{3}$, memperlihatkan tinggi tanaman yang lebih tinggi dan berbeda nyata dibandingkan dengan perlakuan $\mathrm{u}_{0}$ dan $\mathrm{u}_{2}$ tapi pada taraf $\mathrm{u}_{3}$ 
pemberian konsentrasi pupuk hayati bioboost pada taraf $a_{2}$ berbeda tidak nyata. Demikian pula bahwa pada taraf $\mathrm{u}_{3}$, pemberian konsentrasi air kelapa pada taraf $\mathrm{a}_{3}$, memperlihatkan tinggi tanaman yang lebih tinggi dan berbeda nyata dibandingkan dengan perlakuan $a_{0}$ dan $a_{1}$ tapi pada taraf $a_{2}$ berbeda tidak nyata. Atas dasar uraian tersebut terlihat bahwa pemberian konsentrasi pupuk hayati bioboost $120 \mathrm{ml} \mathrm{L}^{-1}\left(\mathrm{u}_{3}\right)$ dengan konsentrasi air kelapa $225 \mathrm{ml} \mathrm{L}^{-1}\left(\mathrm{a}_{3}\right)$ memberikan tinggi tanaman yang lebih baik.

\section{Jumlah Daun (Helai)}

Hasil pengamatan dan analisis data statistik jumlah daun pada umur 14 HST, 21 HST, 28 HST dan 35 HST, analisis menunjukan tidak terjadi interaksi antara konsentrasi pupuk hayati bioboost dan air kelapa pada pertumbuhan tinggi tanaman. Hasil analisis uji mandiri pada pengamatan jumlah anakan per rumpun disajikan pada Tabel 3.

Berdasarkan Tabel 3, hasil analisis uji mandiri menunjukkan bahwa pemberian pupuk hayati bioboost berbeda nyata terhadap pertumbuhan jumlah daun umur (14 HST, 21 HST, 28 HST dan 35 HST). Perlakuan $\mathrm{u}_{3}\left(120 \mathrm{ml} \mathrm{L}^{-1}\right)$ menunjukkan hasil yang tinggi dibandingkan perlakuan lainya. Demikian pula pemberian konsentrasi air kelapa menunjukkan hasil yang berbeda nyata terhadap pertumbuhan tinggi tanaman umur (14 HST, 21 HST, 28 HST dan 35 HST), perlakuan a konsentrasi $\left(225 \mathrm{ml} \mathrm{L}^{-1}\right)$ menunjukkan hasil yang tinggi dibandingkan perlakuan lainya.

Tabel 3. Pengaruh Pemberian Konsentrasi Bioboost dan Air Kelapa terhadap Jumlah Daun Umur 14 HST, 21 HST, 28 HST dan 35 HST.

\begin{tabular}{|c|c|c|c|c|}
\hline \multirow{2}{*}{ Perlakuan } & \multicolumn{4}{|c|}{ Rata-Rata Jumlah Daun (Helai) } \\
\hline & 14 hst & $21 \mathrm{hst}$ & 28 hst & 35 hst \\
\hline $\begin{array}{ll}\text { Pupuk } & \text { hayati } \\
\text { Bioboost } & \end{array}$ & & & & \\
\hline $\mathrm{u}_{0}=0 \mathrm{ml} / \mathrm{L}$ Larutan & $9,58 \mathrm{a}$ & $14,08 \mathrm{a}$ & $20,92 \mathrm{a}$ & $29,08 \mathrm{a}$ \\
\hline $\mathrm{u}_{1}=40 \mathrm{ml} / \mathrm{L}$ Larutan & $9,92 \mathrm{~b}$ & $15,42 \mathrm{~b}$ & $21,83 \mathrm{~b}$ & $30,50 \mathrm{~b}$ \\
\hline $\mathrm{u}_{2}=80 \mathrm{ml} / \mathrm{L}$ Larutan & $10,50 \mathrm{c}$ & $16,95 \mathrm{c}$ & $23,33 \mathrm{c}$ & $32,50 \mathrm{c}$ \\
\hline $\mathrm{u}_{3}=120 \mathrm{ml} / \mathrm{L}$ Larutan & $11,50 \mathrm{~d}$ & $18,25 \mathrm{~d}$ & $25,33 \mathrm{~d}$ & $34,75 \mathrm{~d}$ \\
\hline Air Kelapa & & & & \\
\hline $\mathrm{a}_{0}=0 \mathrm{ml} / \mathrm{L}$ Larutan & $8,67 \mathrm{a}$ & $14,57 \mathrm{a}$ & $20,42 \mathrm{a}$ & $27,42 \mathrm{a}$ \\
\hline $\mathrm{a}_{1}=75 \mathrm{ml} / \mathrm{L}$ Larutan & $10,58 \mathrm{~b}$ & $15,42 \mathrm{~b}$ & $21,92 \mathrm{~b}$ & $31,08 \mathrm{~b}$ \\
\hline $\mathrm{a}_{2}=150 \mathrm{ml} / \mathrm{L}$ Larutan & $10,67 \mathrm{~b}$ & $16,54 \mathrm{c}$ & $23,25 \mathrm{c}$ & $33,25 \mathrm{c}$ \\
\hline $\mathrm{a}_{3}=225 \mathrm{ml} / \mathrm{L}$ Larutan & $11,58 \mathrm{c}$ & $18,17 \mathrm{~d}$ & $25,83 \mathrm{~d}$ & $35,08 \mathrm{~d}$ \\
\hline
\end{tabular}

Keterangan : Angka rata-rata yang diikuti huruf yang sama berbeda tidak nyata berdasarkan Uji Jarak Berganda Duncan pada taraf nyata 5\%. 
Volume Akar (ml)

Tabel 4. Pengaruh Pemberian Konsentrasi Bioboost dan Air Kelapa terhadap Volume Akar.

\begin{tabular}{|c|c|c|c|c|}
\hline \multirow{3}{*}{$\begin{array}{l}\text { Pupuk hayati } \\
\text { Bioboost (u) }\end{array}$} & \multicolumn{4}{|c|}{ Rerata Volume Akar Tanaman (ml) } \\
\hline & \multicolumn{4}{|c|}{ Air kelapa ( a ) } \\
\hline & $a_{0}(0 \mathrm{ml} / \mathrm{L})$ & $a_{1}(75 \mathrm{ml} / \mathrm{L})$ & $a_{2}(150 \mathrm{ml} / \mathrm{L})$ & $\begin{array}{l}\mathrm{a}_{3}(225 \\
\mathrm{ml} / \mathrm{L})\end{array}$ \\
\hline \multirow[t]{2}{*}{$\mathrm{u}_{0}(0 \mathrm{ml} / \mathrm{L})$} & $10,67 \mathrm{a}$ & $17,17 \mathrm{a}$ & $16,67 \mathrm{a}$ & $18,17 \mathrm{a}$ \\
\hline & A & B & B & $\mathrm{C}$ \\
\hline \multirow[t]{2}{*}{$\mathrm{u}_{1}(40 \mathrm{ml} / \mathrm{L})$} & $17,33 \mathrm{~b}$ & $19,50 \mathrm{~b}$ & $21,67 \mathrm{~b}$ & $19,84 \mathrm{~b}$ \\
\hline & A & B & $\mathrm{C}$ & B \\
\hline \multirow[t]{2}{*}{$\mathrm{u}_{2}(80 \mathrm{ml} / \mathrm{L})$} & $17,33 \mathrm{~b}$ & $19,34 \mathrm{~b}$ & $22,34 \mathrm{~b}$ & $23,17 \mathrm{c}$ \\
\hline & A & B & $\mathrm{C}$ & $\mathrm{D}$ \\
\hline \multirow[t]{2}{*}{$\mathrm{u}_{3}(120 \mathrm{ml} / \mathrm{L})$} & $19,50 \mathrm{~b}$ & $20,50 \mathrm{c}$ & $23,50 \mathrm{c}$ & $24,84 \mathrm{~d}$ \\
\hline & A & B & $\mathrm{C}$ & $\mathrm{D}$ \\
\hline
\end{tabular}

Keterangan : Angka rata-rata yang ditandai dengan huruf kecil (arah vertikal) dan huruf kapital (horizontal) yang sama menunjukan berbeda tidak nyata berdasarkan Uji Jarak Berganda Duncan pada taraf nyata 5\%.

Hasil analisis ragam menunjukan terjadi terjadi interaksi antara pemberian konsetrasi pupuk hayati bioboost dan air kelapa terhadap volume akar. Hasil analisis uji lanjutan efek sederhana dengan uji jarak berganda Duncan seperti terlihat pada Tabel 4.

Berdasarkan Tabel 4, menunjukan bahwa pada taraf $a_{3}$, pemberian pupuk hayati bioboost pada taraf $\mathrm{u}_{3}$ memperlihatkan volume akar yang paling tinggi dan berbeda nyata dibandingkan dengan perlakuan $\mathrm{u}_{0}$ dan $\mathrm{u}_{1}$, tapi pada taraf $\mathrm{u}_{2}$ berbeda tidak nyata. Demikian pula bahwa pada taraf $u_{3}$, pemberian air kelapa pada taraf $a_{3}$ memperlihatkan volume akar yang paling tinggi dan berbeda nyata dibandingkan dengan perlakuan $\mathrm{a}_{0}$ dan $\mathrm{a}_{1}$, tapi pada taraf $\mathrm{a}_{2}$ berbeda tidak nyata. Berdasarkan uraian tersebut terlihat bahwa pemberian konsentrasi pupuk hayati bioboost taraf $\mathrm{u}_{3}(120 \mathrm{ml}$ $\left.\mathrm{L}^{-1}\right)$ dengan pemberian air kelapa $\mathrm{a}_{3}\left(225 \mathrm{ml} \mathrm{L}^{-1}\right)$ memberikan volume akar yang lebih tinggi.

\section{Bobot Segar Per Tanaman (g)}

Hasil analisis uji mandiri menunjukkan tidak terjadi interaksi antara pemberian konsentrasi pupuk hayati bioboost disertai konsentrasi air kelapa terhadap bobot segar per tanaman. Hasil analisis uji mandiri dapat dilihat pada Tabel 5. 
Tabel 5. Pengaruh Pemberian Konsentrasi Bioboost dan Air Kelapa terhadap Bobot Segar per Tanaman

\begin{tabular}{lc}
\hline \multicolumn{1}{c}{ Perlakuan } & $\begin{array}{c}\text { Rerata Bobot Basah Tanaman Persampel } \\
\text { (gram) }\end{array}$ \\
\hline Pupuk hayati Bioboost & \\
$\mathrm{u}_{0}=0 \mathrm{ml} / \mathrm{L}$ Larutan & $195,71 \mathrm{a}$ \\
$\mathrm{u}_{1}=40 \mathrm{ml} / \mathrm{L}$ Larutan & $209,51 \mathrm{a}$ \\
$\mathrm{u}_{2}=80 \mathrm{ml} / \mathrm{L}$ Larutan & $209,03 \mathrm{a}$ \\
$\mathrm{u}_{3}=120 \mathrm{ml} /$ L Larutan & $230,27 \mathrm{~b}$ \\
\hline Air Kelapa & \\
$\mathrm{a}_{0}=0 \mathrm{ml} / \mathrm{L}$ Larutan & $199,00 \mathrm{a}$ \\
$\mathrm{a}_{1}=75 \mathrm{ml} / \mathrm{L}$ Larutan & $210,55 \mathrm{~b}$ \\
$\mathrm{a}_{2}=150 \mathrm{ml} /$ L Larutan & $208,84 \mathrm{a}$ \\
$\mathrm{a}_{3}=225 \mathrm{ml} / \mathrm{L}$ Larutan & $226,13 \mathrm{~b}$ \\
\hline
\end{tabular}

Keterangan : Angka rata-rata yang diikuti huruf yang sama berbeda tidak nyata berdasarkan Uji Jarak Berganda Duncan pada taraf nyata 5\%.

Berdasarkan Tabel 5, hasil analasis uji mandiri menunjukkan bahwa pemberian konsentrasi pupuk hayati bioboost dan konsentrasi air kelapa masing-masing berbeda nyata terhadap bobot segar per tanaman. Pemberian konsentrasi pupuk hayati bioboost $\mathrm{u}_{3}\left(120 \mathrm{ml} \mathrm{L}^{-1}\right)$ menunjukkan hasil tertinggi dibandingkan perlakuan lainya. Demikian pula pada pemberian konsentrasi air kelapa $\mathrm{a}_{3}\left(225 \mathrm{ml} \mathrm{L}^{-1}\right)$ menunjukkan hasil tertinggi dibandingkan perlakuan lainya, tetapi dibandingkan pada taraf $a_{1}$ berbeda tidak nyata.

\section{Bobot Segar Per Plot (g)}

Hasil analisis ragam menunjukan terjadi interaksi antara pemberian konsetrasi pupuk hayati bioboost dan air kelapa terhadap bobot segar per plot. Hasil analisis uji lanjutan efek sederhana seperti tersaji pada Tabel 6 . 
Tabel 6. Pengaruh Pemberian Konsentrasi Bioboost dan Air Kelapa terhadap Bobot Segar per Tanaman.

\begin{tabular}{|c|c|c|c|c|}
\hline \multirow{3}{*}{$\begin{array}{l}\text { Pupuk hayati } \\
\text { Bioboost (u) }\end{array}$} & \multicolumn{4}{|c|}{ Rerata Bobot Basah Tanaman Per Plot (gram) } \\
\hline & \multicolumn{4}{|c|}{ Air kelapa ( a ) } \\
\hline & $a_{0}(0 \mathrm{ml} / \mathrm{L})$ & $a_{1}(75 \mathrm{ml} / \mathrm{L})$ & $a_{2}(150 \mathrm{ml} / \mathrm{L})$ & $\begin{array}{l}\mathrm{a}_{3}(225 \\
\mathrm{ml} / \mathrm{L})\end{array}$ \\
\hline $\mathrm{u}_{0}(0 \mathrm{ml} / \mathrm{L})$ & $158,53 \mathrm{a}$ & $192,43 \mathrm{~b}$ & $188,29 \mathrm{~b}$ & $177,72 \mathrm{a}$ \\
\hline & A & $\mathrm{B}$ & B & $\mathrm{B}$ \\
\hline $\mathrm{u}_{1}(40 \mathrm{ml} / \mathrm{L})$ & $\begin{array}{c}165,93 \text { a } \\
\text { A }\end{array}$ & $\begin{array}{c}196,83 \mathrm{~b} \\
\mathrm{~B}\end{array}$ & $\begin{array}{c}170,38 \mathrm{a} \\
\mathrm{A}\end{array}$ & $\begin{array}{c}190,54 \mathrm{a} \\
\mathrm{B}\end{array}$ \\
\hline $\mathrm{u}_{2}(80 \mathrm{ml} / \mathrm{L})$ & $\begin{array}{c}208,92 \mathrm{~b} \\
\text { B }\end{array}$ & $\begin{array}{c}172,93 \mathrm{~b} \\
\mathrm{~A}\end{array}$ & $\begin{array}{c}186,43 \mathrm{~b} \\
\mathrm{~A}\end{array}$ & $\begin{array}{c}227,63 \mathrm{~b} \\
\mathrm{C}\end{array}$ \\
\hline $\mathrm{u}_{3}(120 \mathrm{ml} / \mathrm{L})$ & $\begin{array}{c}212,06 \mathrm{~b} \\
\mathrm{~B}\end{array}$ & $\begin{array}{c}191,12 \mathrm{~b} \\
\mathrm{~A}\end{array}$ & $\begin{array}{c}201,33 \mathrm{~b} \\
\mathrm{AB}\end{array}$ & $\begin{array}{c}238,72 \mathrm{~b} \\
\mathrm{C}\end{array}$ \\
\hline
\end{tabular}

Keterangan : Angka rata-rata yang ditandai dengan huruf kecil (arah vertikal) dan huruf kapital (horizontal) yang sama menunjukan berbeda tidak nyata berdasarkan Uji Jarak Berganda Duncan pada taraf nyata 5\%.

Berdasarkan Tabel 6, menunjukan bahwa pada taraf $a_{3}$, pemberian pupuk hayati bioboost pada taraf $\mathrm{u}_{3}$ memperlihatkan volume akar yang paling tinggi dan berbeda nyata dibandingkan dengan perlakuan $\mathrm{u}_{0}$ dan $\mathrm{u}_{1}$, tapi pada taraf $\mathrm{u}_{2}$ berbeda tidak nyata, pada taraf $\mathrm{u}_{3}$, kemudian pemberian air kelapa pada taraf $\mathrm{u}_{3}$ memperlihatkan volume akar yang paling tinggi dan berbeda nyata dibandingkan dengan perlakuan lainya $\left(a_{0}, a_{1}\right.$ dan $\left.a_{2}\right)$.Atas dasar uraian tersebut terlihat bahwa pemberian konsentrasi pupuk hayati bioboost taraf $\mathrm{u}_{3}\left(120 \mathrm{ml} \mathrm{L}^{-1}\right)$ dengan pemberian air kelapa $\mathrm{a}_{3}(225 \mathrm{ml} \mathrm{L}$ $\left.{ }^{1}\right)$ memberikan bobot segar per plot yang lebih baik.

\section{Bobot Kering (g)}

Hasil analisis uji mandiri menunjukkan tidak terjadi interaksi antara pemberian konsentrasi pupuk hayati bioboost disertai konsentrasi air kelapa terhadap bobot kering tanaman. Hasil analisis uji mandiri dapat dilihat pada (Tabel 7).

Tabel 7. Pengaruh Pemberian Konsentrasi Bioboost dan Air Kelapa terhadap Bobot Kering.

\begin{tabular}{lc}
\hline Perlakuan & Rata-Rata Bobot Kering Tanaman (gram) \\
\hline Pupuk hayati Bioboost & \\
$\mathrm{u}_{0}=0 \mathrm{ml} /$ L Larutan & $16,61 \mathrm{a}$ \\
$\mathrm{u}_{1}=40 \mathrm{ml} /$ L Larutan & $19,26 \mathrm{a}$ \\
$\mathrm{u}_{2}=80 \mathrm{ml} /$ L Larutan & $20,25 \mathrm{a}$ \\
$\mathrm{u}_{3}=120 \mathrm{ml} /$ L Larutan & $24,24 \mathrm{~b}$ \\
\hline Air Kelapa & \\
$\mathrm{a}_{0}=0 \mathrm{ml} /$ L Larutan & $16,14 \mathrm{a}$ \\
$\mathrm{a}_{1}=75 \mathrm{ml} /$ L Larutan & $20,03 \mathrm{~b}$ \\
$\mathrm{a}_{2}=150 \mathrm{ml} /$ L Larutan & $21,02 \mathrm{~b}$ \\
$\mathrm{a}_{3}=225 \mathrm{ml} /$ L Larutan & $23,18 \mathrm{~b}$ \\
\hline
\end{tabular}

Keterangan : Angka rata-rata yang diikuti huruf yang sama berbeda tidak nyata berdasarkan

Uji Jarak Berganda Duncan pada taraf nyata 5\%.

PENGARUH $\quad$ KONSENTRASI $\quad$ PUPUK

HAYATI BIOBOOST DAN AIR KELAPA

TERHADAP PERTUMBUHAN DAN HASIL

TANAMAN SELADA ( Lactuca sativa L.)

VARIETAS GRAND RAPIDS
KOVERTINA RAKHMI INDRIANA RICKY HASRAT DIRMAWAN dan AI KOMARIAH 
Berdasarkan Tabel 7, hasil analasis uji mandiri menunjukkan bahwa pemberian konsentrasi pupuk hayati bioboost dan konsentrasi air kelapa masing-masing berbeda nyata terhadap bobot kering. Pemberian konsentrasi pupuk hayati bioboost $\mathrm{u}_{3}(120$ $\mathrm{ml} \mathrm{L}^{-1}$ ) menunjukkan hasil tertinggi dibandingkan perlakuan lainya. Demikian pula pada pemberian konsentrasi air kelapa $\mathrm{a}_{3}\left(225 \mathrm{ml} \mathrm{L}^{-1}\right)$ menunjukkan hasil tertinggi dibandingkan perlakuan lainya, tetapi dibandingkan pada taraf $\mathrm{a}_{1}$ dan $\mathrm{a}_{2}$ berbeda tidak nyata.

\section{Nisbah Pupus Akar (g)}

Hasil analisis ragam menunjukan terjadi interaksi antara pemberian konsetrasi pupuk hayati bioboost dan air kelapa terhadap nisbah pupus akar. Hasil analisis uji lanjutan efek sederhana seperti tersaji pada Tabel 8.

Tabel 8. Pengaruh Pemberian Konsentrasi Bioboost dan Air Kelapa terhadap Nisbah Pupus Akar.

\begin{tabular}{|c|c|c|c|c|}
\hline \multirow{3}{*}{$\begin{array}{l}\text { Pupuk hayati } \\
\text { Bioboost (u) }\end{array}$} & \multicolumn{4}{|c|}{ Rerata Nisbah Pupus Akar Tanaman (gram) } \\
\hline & \multicolumn{4}{|c|}{ Air kelapa ( a ) } \\
\hline & a0 $(0 \mathrm{ml} / \mathrm{L})$ & a1 $(75 \mathrm{ml} / \mathrm{L})$ & a2 $(150 \mathrm{ml} / \mathrm{L})$ & $\begin{array}{c}\mathrm{a} 3(225 \\
\mathrm{ml} / \mathrm{L})\end{array}$ \\
\hline $\mathrm{u} 0(0 \mathrm{ml} / \mathrm{L})$ & $\begin{array}{c}15,28 \mathrm{a} \\
\mathrm{A}\end{array}$ & $\begin{array}{c}23,47 \mathrm{a} \\
\mathrm{B}\end{array}$ & $\begin{array}{c}26,46 a b \\
B\end{array}$ & $\begin{array}{c}33,74 \mathrm{~b} \\
\mathrm{C}\end{array}$ \\
\hline $\mathrm{u} 1(40 \mathrm{ml} / \mathrm{L})$ & $\begin{array}{c}23,47 \mathrm{~b} \\
\mathrm{~A}\end{array}$ & $\begin{array}{c}25,34 \mathrm{a} \\
\mathrm{A}\end{array}$ & $\begin{array}{c}30,54 \mathrm{c} \\
\mathrm{B}\end{array}$ & $\begin{array}{c}32,69 \mathrm{ab} \\
\mathrm{B}\end{array}$ \\
\hline u2 $(80 \mathrm{ml} / \mathrm{L})$ & $\begin{array}{c}28,56 \mathrm{c} \\
\mathrm{A}\end{array}$ & $\begin{array}{c}26,26 \mathrm{a} \\
\mathrm{A}\end{array}$ & $\begin{array}{c}29,05 \mathrm{bc} \\
\mathrm{AB}\end{array}$ & $\begin{array}{c}31,21 \mathrm{a} \\
\mathrm{B}\end{array}$ \\
\hline $\mathrm{u} 3(120 \mathrm{ml} / \mathrm{L})$ & $\begin{array}{c}28,56 \mathrm{c} \\
\mathrm{A}\end{array}$ & $\begin{array}{c}24,22 \mathrm{a} \\
\mathrm{A}\end{array}$ & $\begin{array}{c}23,68 \text { a } \\
\text { A }\end{array}$ & $\begin{array}{c}29,89 \mathrm{a} \\
\text { B }\end{array}$ \\
\hline
\end{tabular}

Keterangan : Angka rata-rata yang ditandai dengan huruf kecil (arah vertikal) dan huruf kapital (horizontal) yang sama menunjukan berbeda tidak nyata berdasarkan Uji Jarak Berganda Duncan pada taraf nyata 5\%.

Berdasarkan Tabel 8, menunjukan bahwa pada taraf $a_{3,}$, pemberian pupuk hayati bioboost pada taraf $\mathrm{u}_{0}$ memperlihatkan volume akar yang paling tinggi dan berbeda nyata dibandingkan dengan perlakuan lainya $\left(\mathrm{u}_{1}, \mathrm{u}_{2}\right.$ dan $\left.\mathrm{u}_{3}\right)$. Demikian pula bahwa pada taraf $\mathrm{u}_{0}$ dan $\mathrm{u}_{1}$, pemberian air kelapa pada taraf $\mathrm{a}_{3}$ memperlihatkan volume akar yang paling tinggi dan berbeda nyata dibandingkan dengan perlakuan $a_{0}$ dan $a_{1}$, tapi pada taraf $\mathrm{a}_{2}$ berbeda tidak nyata. Atas dasar uraian tersebut terlihat bahwa pemberian konsentrasi pupuk hayati bioboost taraf $\mathrm{u}_{0}\left(0 \mathrm{ml} \mathrm{L}^{-1}\right)$ dan $\mathrm{u}_{1}\left(40 \mathrm{ml} \mathrm{L}^{-1}\right)$ dengan pemberian air kelapa $a_{3}\left(225 \mathrm{ml} \mathrm{L}^{-1}\right)$ memberikan bobot segar per plot yang lebih baik.

\section{B. Pembahasan}

Berdasarkan hasil pengamatan dan hasil analisis, maka pemberian perlakuan pupuk hayati bioboost dan air kelapa dengan konsentrasi yang berbeda menunjukan 
pengaruh yang berbeda pula terhadap pertumbuhan dan hasil tanaman selada varietas grand rapids. Hasil percobaan menunjukan adanya interaksi terhadap tinggi tanaman umur 35 HST, volume akar, bobot segar per plot dan nisbah pupus akar. Sedangkan pada tinggi tanaman (14 HST, 21 HST, 28 HST),jumlah daun (14 HST, 21 HST, 28 HST ,35 HST), bobot segar per tanaman dan bobot kering tidak terjadi interaksi.

Pemberian pupuk hayati bioboost berupa mikroba tanah disertai air kelapa dapat mempengaruhi sifat fisik, kimia dan biologi tanah. Dengan demikian lingkungan tumbuhan tanaman akan semakin baik. Ketersediaan unsur hara di dalam tanah yang akan mempengaruhi pertumbuhan dan perkembangan tanaman. Apabila ketersediaan unsur hara dalam tanah cukup, maka pertumbuhan perkembangan tanaman dan kemampuan akar dalam menyerap unsur hara akan semakin baik. Menurut Simanungkalit, (2001) bahwa mikro organisme aktif yang terkandung dalam pupuk hayati mampu menambat Nitrogen $(\mathrm{N})$ untuk tanaman, melarutkan senyawa Phosfat $(\mathrm{P})$ dan melepaskan senyawa Kalium (K) dari ikatan koloid tanah sehingga unsur hara makro mikro dapat tercukupi untuk proses vegetatif dan generatif tanaman.

Menurut Wilujeng, et al. (2017) menyatakan bahwa aktivitas berbagai mikroorganisme di dalam pupuk hayati menghasilkan hormon-hormon pertumbuhan seperti auksin, giberelin, dan sitokinin yang dapat memacu pertumbuhan tanaman. Hasil analisis secara mandiri, pemberian konsentrasi pupuk hayati dan air kelapa menunjukkan adanya pengaruh yang berbeda nyata terhadap jumlah daun (14 HST, 21 HST, 28 HST, 35 HST), volume akar, bobot segar per tanaman,bobot segar per plot, bobot kering tanaman dan nisbah pupus akar, hal ini menunjukkan bahwa peningkatan mikroba dalam tanah semakin baik dalam menjaga kesuburan tanah yang menyebabkan pertumbuhan vegetatif tanaman dan hasil produksi tanaman.

Interaksi pupuk hayati bioboost dan air kelapa menunjukan adanya pengaruh terhadap pengamatan tinggi tanaman pada umur 35 HST, volume akar, bobot segar per plot dan nisbah pupus akar pada umur 35 HST. Hal ini karena pemberian pupuk hayati bioboost dan air kelapa terhadap tanaman selada dapat meningkatkan pertumbuhan tanaman sehingga masing-masing komponen berpengaruh secara bersama-sama kemudian membantu proses aktifitas perkembangan mikroba dalam tanah yang dapat menghasilkan hormon-hormon pertumbuhan misalnya auksin,giberelin yang memacu pertumbuhan dan perkembangan akar-akar rambut sehingga daerah pencarian makanan menjadi lebih luas. Pertumbuhan tinggi tanaman juga dipengaruhi oleh unur hara yang diserap akar dijadikan sebagai bahan makanan. (latarang dan syakur, 2006). Kemudian menurut Rahmawati, S (2006), pupuk hayati dapat meningkatkan ketersedian nitrogen dalam tanah dan meningkatkan serapan nitrogen, untuk pembentukan klorofil dan merangsang pertumbuhan vegetatipe tanaman seperti batang, cabang, dan daun.

Sesuai dengan pendapat Saifuddin Sarief (1989), apabila unsur nitrogen yang tersedia cukup dapat menghasilkan protein yang banyak dan daun dapat tumbuh

PENGARUH $\quad$ KONSENTRASI $\quad$ PUPUK HAYATI BIOBOOST DAN AIR KELAPA TERHADAP PERTUMBUHAN DAN HASIL TANAMAN SELADA ( Lactuca sativa L.)

VARIETAS GRAND RAPIDS
KOVERTINA RAKHMI INDRIANA RICKY HASRAT DIRMAWAN dan AI KOMARIAH 
banyak. Banyaknya jumlah daun per tanaman akan mendorong klorofil semakin giat dalam proses fotosintesis, sehingga hasil fotosintesis berupa karbohidrat, protein, lemak, mineral, vitamin dan energi semakin banyak pula (Sri Setyati Harjadi, 1991). Selanjutnya tanaman menggunakan hasil fotosintesis untuk perbanyakan sel maupun perpanjangan sel. Tersedianya karbohidrat yang menjadi bahan untuk pembelahan sel banyak, maka tinggi tanaman, jumlah cabang per tanaman serta bobot kering tanaman menjadi baik, sejalan dengan ungkapan Sarwono Hardjowigeno (1995) suplai unsur hara memegang peranan penting untuk membangun tubuh tanaman karena unsur hara sangan mempengaruhi proses metabolisme yang terjadi dalam tanaman.

Pada deskripsi tanaman selada, produksi tanaman ini pada umumnya menghasilkan 10 ton/ha sampai 15 ton/ha sedangkan pada hasil penelitian ini mencapai 25 ton/ha. Hal ini disebabkan pengaruh pemberian konsentrasi pupuk bioboost dan air kelapa dapat meningkatkan bobot segar per tanaman dan per plot. Peningkatan bobot segar per tanaman disebabkan pada konsentrasi pupuk hayati bioboost $120 \mathrm{ml} \mathrm{L}^{-1}$ dan air kelapa $225 \mathrm{ml} \mathrm{L}^{-1}$ ketersediaan unsur hara makro dan mikro mencukupi, hal ini disebabkan kandungan hara $\mathrm{N}$, dan $\mathrm{P}$ dalam tanah terbilang cukup maksimal, bahwasanya jika kandungan hara dalam tanah melebihi batas yang dibutuhkan tanaman, sehingga proses fotosintesis tanaman tidak mengalami hambatan dan fotosintat yang terbentuk relatif lebih banyak. Fotosintat tersebut oleh tanaman ditranslokasikan ke seluruh organ tanaman sehingga hasil tanaman selada mengalami peningkatan pertumbuhan dan hasil.

\section{PENUTUP}

\section{Kesimpulan}

Berdasarkan hasil percobaan dan pembahasan dapat ditarik kesimpulan sebagai berikut:

1. Terjadi interaksi antara pemberian konsentrasi pupuk hayati bioboost dan air kelapa terhadap pertumbuhan dan hasil tanaman selada varietas grand rapids yaitu pada tingggi tanaman 35 HST, volume akar, bobot segar per plot dan nisbah pupus akar. Sedangkan pada tinggi tanaman (14 HST, 21 HST, 28 HST), jumlah daun (14 HST, 21 HST, 28 HST ,35 HST), bobot segar per tanaman dan bobot kering tidak terjadi interaksi.

2. Pemberian pupuk hayati bioboost pada konsentrasi $120 \mathrm{ml} \mathrm{L}^{-1}$ dengan air kelapa pada konsentrasi $225 \mathrm{ml} \mathrm{L}^{-1}$ menghasilkan produksi tanaman selada terbaik ( tinggi tanaman 35,85 cm, volume akar 24,84 $\mathrm{ml}$, bobot segar per plot 238,72 g dan Nisbah Pupus Akar 32,69 ml).

3. Secara mandiri perlakuan pemberian kosentrasi pupuk hayati bioboost dan air kelapa berpengaruh nyata terhadap pertumbuhan dan hasil.

PENGARUH $\quad$ KONSENTRASI PUPUK

HAYATI BIOBOOST DAN AIR KELAPA

TERHADAP PERTUMBUHAN DAN HASIL

TANAMAN SELADA ( Lactuca sativa L.)

VARIETAS GRAND RAPIDS
KOVERTINA RAKHMI INDRIANA RICKY HASRAT DIRMAWAN dan AI KOMARIAH 


\section{Saran}

Untuk meningkatkan hasil pada budidaya tanaman selada varietas grand rapids dianjurkan untuk menambah taraf konsentrasi pupuk hayati bioboost dan air kelapa lebih tinggi dari $120 \mathrm{ml} \mathrm{L}^{-1}$ dan $225 \mathrm{ml} \mathrm{L} \mathrm{L}^{-1}$, agar dapat mengentahui titik konstan dari pengaruh pupuk hayati bioboost dan air kelapa. Oleh karna itu perlu dilakukan penelitian lebih lanjut untuk memperoleh informasi yang lebih lengkap dengan perlakuan yang serupa, akan tetapi dilakukan dilapangan pada lahan pertanian.

\section{DAFTAR PUSTAKA}

Bargumono. (2016). Pertanian Organik Solusi Alternaif Pertanian. Global Pustaka Utama.Yogyakarta.

Badan Pusat Statistik. (2016). Produksi dan Produktivitas Selada 2010-2015. http://www.bps.go.id. Diakses pada tanggal 15 juni 2020.

Bioboostsakti. (2016). Isi dan Kandungan Pupuk Hayati Bioboost. https://bioboostsakti.blogspot.com. Diakses melalui internet pada tanggal 14 mei 2020.

Hartatik, W. D. Setyorini dan S. Widati. (2006). Laporan Penelitian Teknologi Pengelolahan Hara Pada Budidaya Pertanian Organik. Balai Peneliti Tanah. Bogor.

Latarang, B. dan A Syakur. (2006). Pertumbuhan dan Hasil Bawang Merah (Allium ascaloicum L.) pada Berbagai Dosis Pupuk Kandang. Jurnal Agroland. Vol 13: 265-269.

Rahmawati, S. (2006). Status Perkembangan Perbaikan Sifat Genetik Padi Menggunakan Transformasi argobacterium. Jurnal Agrobiogen. 2 (1): 36 - 44.

Saifuddin Sarief, E. (1989). Kesuburan Tanah dan Pemupukan Tanah. Pustaka Buana, Bandung.

Sarwono Hardjowigeno. (1992). Ilmu Tanah. Akademika Pressindo : Jakarta.

Simanungkalit, R.D.M. and R. R. Saras Wati. (2001). Application of biotechnology on biofertilizer production in Indonesia.

Sri Setyadi Hajadi. (1995). Pengantar Agronomi. Gramedia: Jakarta.

Sunarjono. (2007). Budidaya Tanaman Selada. Penebar Swadaya: Bandung.

UPTD. (2019). Pemetaan Wilayah Program Penyuluh Pertanian 2015-2019. Kec. Ganeas .Kab. Sumedang :UPTD.

USDA. (2014). National Nutrient Database for Standard Reference of raw garlic. Agricultural Research Service. United States: Department of Agriculture. https://ndb.nal.usda.gov/ndb/foods/show/2017. Diakses 16 juni 2020.

Wilujeng, S. \& Agustini, V. (2017). Studi Awal Kultur Biji Sowang (Xanthostemon novaguineense Valet.) Secara In-vitro. Jurnal Biodjati. 2(1):64-71.

PENGARUH $\quad$ KONSENTRASI PUPUK

HAYATI BIOBOOST DAN AIR KELAPA

TERHADAP PERTUMBUHAN DAN HASIL

TANAMAN SELADA ( Lactuca sativa L.)

VARIETAS GRAND RAPIDS
KOVERTINA RAKHMI INDRIANA RICKY HASRAT DIRMAWAN dan AI KOMARIAH 